\title{
Geyikli (Çanakkale, Turkey) Heavy Mineral Sands: Insights to Their Origin Related with Alkaline Intrusive Rocks
}

\author{
Ali Tugcan UNLUERA ${ }^{\text {(D) }}$, Huseyin KOCATURKa. * (D) Zeynep DONER ${ }^{a}$ (D) Mustafa KAYA $^{\mathrm{a}}$ (D) \\ Demet Kiran YILDIRIMa ${ }^{a}$, Mustafa KUMRAL ${ }^{\text {(D) Senel OZDAMAR }}{ }^{a}$
}

a Istanbul Technical University, Faculty of Mines, Department of Geological Engineering, TR-34467, Istanbul Turkey

\section{ARTICLEINFO}

\section{Article history:}

Received 00 December 20 March 2021

Received in revised form 07 May 2021

Accepted 07 May 2021

\section{Keywords:}

Rare Earth Elements (REE)

Essexite

Placer

Heavy Mineral Sand

\begin{abstract}
A B S T R AC T
Essexites of Kestanbol pluton have significant amount of iron (Fe), titanium (Ti), Rare Earth Elements (REE) and thorium (Th) and considered as the source of Geyikli Heavy Mineral Sands (HMS). Geyikli HMS were enriched by the minerals of magnetite, rutile, monazite and apatite. In Geyikli HMS, REE contents (up to $0,25 \%$ ) were rised by $4-5$ times during placer deposition, mainly caused by the enriching of weathering resistant REE bearing dense phosphate minerals and zircon. On the other hand, Fe (up to $11 \%$ ) and $\mathrm{Ti}$ (up to $2,5 \%$ ) enrichments are heavily dependent on the magnetite, titanomagnetite and rutile minerals. By using the basic physical mineral processing techniques such sieving, shaking tables, multi gravity seperators, magnetic seperation, it is possible to reach higher grades for both REE and Fe-Ti and to have better initial values for electrochemical mineral processing techniques.
\end{abstract}

(c) 2021. Turkish Journal Park Academic. All rights reserved.

\section{Introduction}

Heavy Mineral Sand deposits are hosted for a variety of strategic element enrichments which include Rare Earth Elements, Thorium, Uranium, Iron, Titanium and Zircon. In Turkey a few number of heavy mineral placers (Ormanl, İstanbul; Karasu and Melen Sakarya; Ünye, Ordu;) are identified (Mugan and Ipekoğlu 1995). Most of these mineralizations are relatively small and commercial mining in these placers are not financialy feasible.

The Geyikli Heavy Mineral Sands located in Çanakkale area is one of the most famous placers in Turkey (Andac 1973) This study focuses on the geochemical mineralogical properties of
Geyikli Heavy Mineral Sands and their origin. Previous studies indicated that the main minerals in Geyikli placer are magnetite, sphene, zircon, anatase, korund, thorite and uranothorite (Mücke and Andac, 1975; Örgün et al. 2007). Similar to the other beach sand deposits which originated from felsic or alkaline magmatic rocks, Geyikli placer's main heavy mineral source is Kestanbol pluton (Andac 1973).

\section{Material and Methods}

Thirteen placer and five essexite samples gathered from the study area during field work. Whole-rock (major and trace element) analyses were conducted on powders grounded using an agate mortar muller milling device. Using a Bruker S8

\footnotetext{
* Corresponding author. Tel.: +90 2122856307

E-mail address: kocaturkhu@itu.edu.tr

ORCID : 0000-0003-0382-4059 (Ali Tugcan.Unluer), 0000-0002-5131-8807 (Huseyin.Kocaturk), 0000-0003-2928-3174 (Zeynep.Doner), 0000-0003-0694-9754 (Mustafa.Kaya), 0000-0001-5995-5723 (Demet.Yildirim), 0000-0001-7827-8721 (Mustafa.Kumral), 0000-0002-4706-8585 (Senel,Ozdamar)
} 
Tiger X-ray fluorescence (XRF) spectrometer with wavelength ranges from $0.01-12 \mathrm{~nm}$, the oxides of major elements, including $\mathrm{SiO}_{2}, \mathrm{Al}_{2} \mathrm{O}_{3}, \mathrm{CaO}, \mathrm{K}_{2} \mathrm{O}, \mathrm{Na}_{2} \mathrm{O}, \mathrm{Fe}_{2} \mathrm{O}_{3}, \mathrm{MnO}, \mathrm{MgO}, \mathrm{TiO}_{2}$, and $\mathrm{P}_{2} \mathrm{O}_{5}$, were determined; the analytical uncertainty is usually $<5 \%$. Elemental analyses were conducted on powders grounded using an agate mortar muller milling device for Elan DRC-e Perkin Elmer Inductively Coupled Plasma-Mass Spectrometry(ICP-MS) in Geochemistry Research Laboratories of Istanbul Technical University (ITU/JAL) to determine the U, Th and REE element contents. A two-step digestion process used approximately $50 \mathrm{mg}$ of powdered samples: (1) $6 \mathrm{ml}$ of $37 \% \mathrm{HCl}, 2 \mathrm{ml}$ of $65 \% \mathrm{HNO}_{3}$ and $1 \mathrm{ml}$ of $38-40 \% \mathrm{HF}$ acid mixer put in a pressure- and temperature-controlled Teflon beaker using a Berghoff Microwave at $135^{\circ} \mathrm{C}$; (2) $6 \mathrm{ml}$ of $5 \%$ boric acid solution was added to the step one mixer for ICP-MS analyses.

\section{Geological Setting}

Biga Peninsula Northwestern Anatolia (Turkey) widespread Cenozoic magmatism occured in Middle Eocene after the continental collision between the Sakarya Zone and AnatolideTauride blocks. As a result of this magmatism, various granitoids were emplaced into the crystalline basement rocks of the Sakarya continent in Eocene-Miocene period with similar geochemical and mineralogical signatures (High-K, calcalkaline, I-type granitoids). N-S trending Kestanbol pluton is an elliptical granitoid body which emplaced into regionally metamorphosed basement rocks. East and southeast borders of the plutonic body is surrounded with Miocene acidic to intermediate volcanic and pyroclastic rocks (rhyolite, rhyodacite lavas and andesitic-trachyandesitic pyroclastic rocks) (Karacık and Yılmaz, 1998). The Plio-Quaternary sedimentary units are observable in west and northwest borders of the pluton (Karacık and Yılmaz, 1998) (Figure 1).

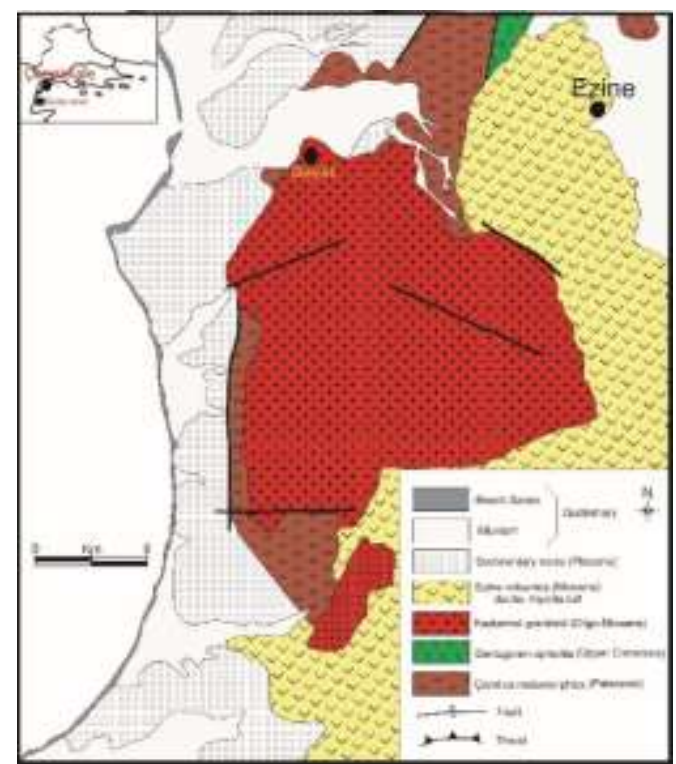

Figure 1. Geological map of the study area modified from Örgün et al., (2007).

\section{Petrographical, Mineralogical and Geochemical Properties of Kestanbol Pluton \& Geyikli Heavy Mineral Sands}

\subsection{Petrography of Kestanbol Pluton and Essexites}

The pluton is mainly composed of quartzmonzonitic and monzodioritic rocks with a mineral paragenesis of orthoclase, plagioclase, quartz, hornblende, biotite and accessorry minerals magnetite, ilmenite, rutile, pyrite, zircon, allanite, apatite, epidote, thorite and uranothorite (Örgün et al., 2007). In this study it is concluded that the main heavy mineral source rocks are essexitic rocks of the outward zones of Kestanbol pluton, located between Kemallı and Aladağ villages.

The essexites in the study area are described as medium to coarse grained, greyish to greenish colored rocks. These rocks display holocrystalline, hipidiomorphic granular texture or porphyritic in contact zone.

The rocks show evidence for cataclasm and alteration in some zones and made up of pyroxene $(30-35 \%$ by volume), plagioclase $(20-25 \%$ by volume $)$ amphibole $(20-25 \%$ by volume), K-feldpars (20-30\% by volume) as major minerals and zircon, apatite, monazite as accesorry minerals (Figure 2).

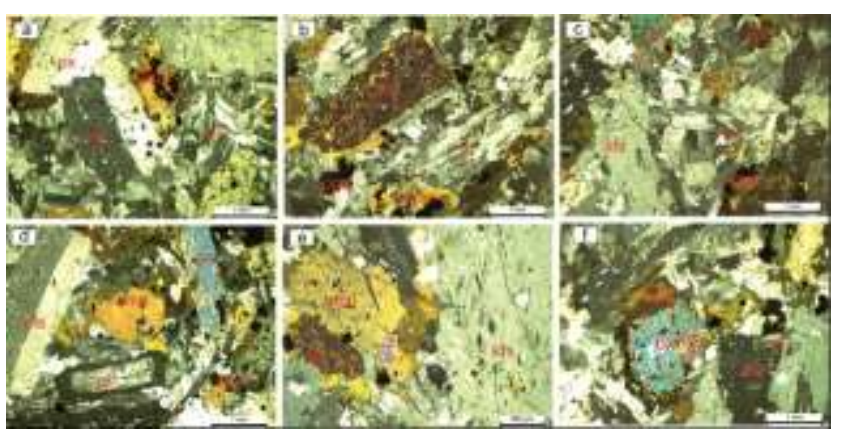

Figure 2. Photomicrographs showing petrographical characteristics of the studied plutonic rock K-feldspars display poiklitic texture $(\mathrm{a}, \mathrm{c}, \mathrm{f})$; pyroxenes are altered to amphiboles $(\mathrm{a}, \mathrm{f})$ plagioclase minerals are shows twining and displays zoned texture.

In pyroxene minerals uralitization and chloritization alterations are common and plagioclase minerals are altered to smectite and secondary calcite minerals. According to the mineralogical data obtained from the rocks can be described as essexite and petrographical studies are consistent with whole rock chemical composition (Table 1).

\subsection{Geochemical Studies}

Kestanbol granitoid in the region can be considered as alkaline intermediate granitoids. The major-element oxides (in \%) and trace \& rare earth (REE) elements of Kestenbol monzodiorite (Altunkaynak et al. 2012), essexite and Geyikli HMS are shown in Table 1. 
Table 1. Average contents of major-element oxides (in \%) and trace \& rare earth (REE) elements (in ppm) of the studied Kestenbol essexite and Geyikli Heavy Mineral Sand, with the average content of the Kestanbol monzodiorite from Altunkaynak et al. (2012).

\begin{tabular}{|c|c|c|c|c|c|c|c|c|c|c|c|c|c|c|c|c|c|c|}
\hline \multirow{2}{*}{\multicolumn{2}{|c|}{ Sample }} & \multicolumn{17}{|c|}{ Major-Hement Oxides } \\
\hline & & $\mathrm{SiO}_{\mathrm{O}}$ & & $\mathrm{Al}_{2} \mathrm{O}_{3}$ & & $\mathrm{e}_{2} \mathrm{O}_{3}$ & MgO & & $\mathrm{CaO}$ & $\mathrm{Na}_{2} \mathrm{O}$ & & $\mathrm{K}_{2} \mathrm{O}$ & $\mathrm{TiO}_{2}$ & $\mathbf{P}_{2} \mathrm{O}_{5}$ & & MnO & & OI \\
\hline \multicolumn{2}{|c|}{$\begin{array}{c}\text { Kestanbol } \\
\text { monzodiorite }\end{array}$} & 60.3 & & 17.4 & & 4.29 & 1.50 & & 3.77 & 3.20 & & 6.35 & 0.45 & 0.30 & & 0.10 & & 152 \\
\hline \multicolumn{2}{|c|}{$\begin{array}{l}\text { Kestanbol } \\
\text { Essexite }\end{array}$} & 54.1 & & 16.3 & & 6.63 & 2.52 & & 6.58 & 3.48 & & 7.17 & 0.84 & 0.69 & & 0.13 & & 91 \\
\hline \multicolumn{2}{|c|}{ Geyikli HMS } & 52.1 & & 9.32 & & 13.9 & 1.55 & & 6.16 & 3.37 & & 4.27 & 3.17 & 0.60 & & 0.07 & & .12 \\
\hline \multicolumn{19}{|c|}{ Rare Earth and Trace Elements } \\
\hline Sample & La & ce & Pr & $\mathrm{Nd}$ & $\mathrm{Sm}$ & Eu & Gd & $\mathrm{Tb}$ & Dy & но & Er & $\begin{array}{ll}\mathrm{Tm} & \mathrm{yb}\end{array}$ & th $\quad$ Lu $\quad \sum R E$ & $\mathrm{E} \quad \mathrm{Y}$ & Th & $\mathrm{u}$ & $\mathrm{Nb}$ & $\mathrm{zr}$ \\
\hline $\begin{array}{c}\text { Kestanbol } \\
\text { monzodionite }\end{array}$ & 81.0 & 156.1 & 15.2 & 61.4 & 10.3 & 3.30 & 7.58 & 1.32 & 4.34 & $0.76 \quad 2$ & 2.51 & $0.27 \quad 1.76$ & $\begin{array}{lll}76 & 0.25 & 346\end{array}$ & 124.5 & 35.0 & 7.90 & 14.6 & 319 \\
\hline $\begin{array}{c}\text { Kestanbol } \\
\text { Essexite }\end{array}$ & 121.1 & 234.2 & 25.8 & 95.1 & 15.7 & 4.02 & 12.4 & 1.70 & 6.78 & $1.05 \quad 3$. & 3.180 & $0.34 \quad 2.58$ & $\begin{array}{lll}.58 & 0.38 & 524 .\end{array}$ & 231.5 & 101.6 & 35.2 & 70.07 & 700.0 \\
\hline eyiki HMS & 515.3 & 1007 & 109.6 & 384.0 & 64.3 & 8.67 & 52.8 & 6.71 & 32.1 & $5.36 \quad 16$ & 16.21 & $1.96 \quad 13$. & $\begin{array}{lll}3.4 & 1.87 \quad 2219\end{array}$ & 9155.7 & 162.0 & 61.0 & 153.03 & 3 \\
\hline
\end{tabular}

The higher total alkali content in essexites than Kestanbol monzodiorites indicates that the essexitic rocks were formed from a less fractioned magma. The studied essexite samples fall in the A-type and Within-Plate granites sections of geotectonic discrimination diagrams, showing that a strong post-collisional character and slight affinity for Syn-collision granites (Figure 3).
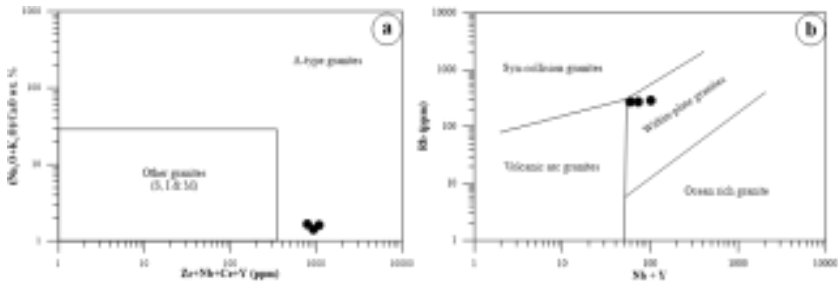

Figure 3. Plots of a) $\mathrm{Zr}+\mathrm{Rb}+\mathrm{Ce}+\mathrm{Y}$ vs. $\left(\mathrm{Na}_{2} \mathrm{O}+\mathrm{K}_{2} \mathrm{O}\right) / \mathrm{CaO}$, (Whalen et al, 1987) b) $\mathrm{Rb}$ vs. $\mathrm{Nb}+\mathrm{Y}$, showing geotectonic discrimination of the studied rocks (Pearce et al. 1984).

Kestanbol granitoid's essexitic rocks are more enriched in terms of the incompatible elements than rocks located in the remaining parts of the granitoid body. This enrichment can be explained with the decreasing of silica and increasing of total alkali content. Studied essexitic rocks show enrichments in both LILE (K, Ba, Sr) and HFSE (REE, Th, U) due to the less fractionated magma and potassic-alkaline nature of the rocks as shown in Figure 4, all Kestanbol rocks show Nb, Ti and $\mathrm{P}$ depletion. In addition, the high $\mathrm{Pb}$ values indicate the crustal contamination in magma chamber.

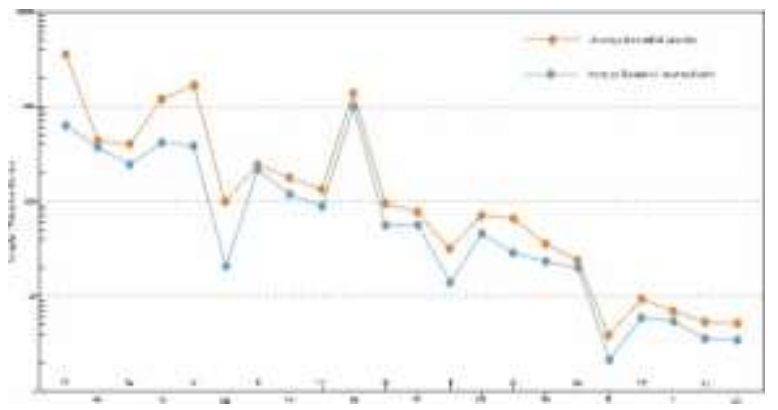

Figure 4. Spider diagram for Essexitic rocks and the remaining average Kestanbol pluton (Sun and Mcdonough 1989).

\subsection{Evaluation of the Geyikli Heavy Mineral Sands}

The Geyikli HMS are enriched in most of the heavy minerals and related elements such as Fe, Ti, Zr and REE. The Zr and REE contents were enriched 4 to 5 times during placer deposition. Moreover, Heavy Rare Earth Elements (HREE) were more enriched than Light Rare Earth Elements (LREE). It can be stated that the HREE enrichments are closely related with the zircon mineral, having the similar enrichment factors (Figure $5)$. The positive correlation between $\mathrm{P}_{2} \mathrm{O}_{5}$ and LREE are observed, pointing out that main LREE bearing minerals are either monazite, xenotime or apatite.

The REE bearing phosphate minerals such as apatite, monazite or xenotime mainly occur in early stages of the fractional crystallization (Kogarko 2018) suggesting that the REE enrichment was not related with any hydrothermal activity in resource rocks.

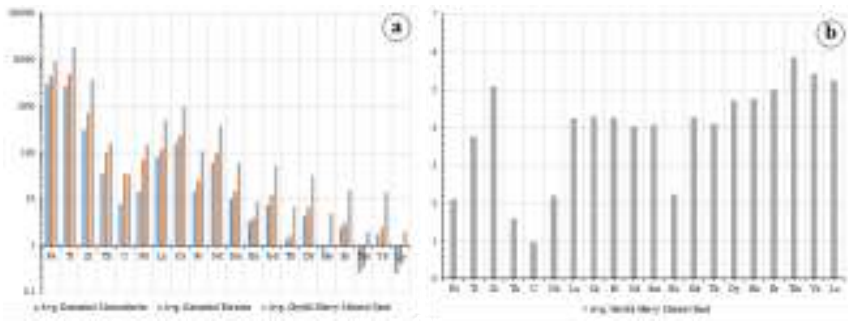

Figure 5. a) Relative enrichment of elements b) Enrichment factor of Geyikli Heavy Mineral Sand relative to Kestanbol essexite.

Geyikli Heavy Mineral Sands were enriched in heavy minerals such as magnetite, titanomagnetite, hematite zircon, rutile, and apatite according to XRD (Figure 6).

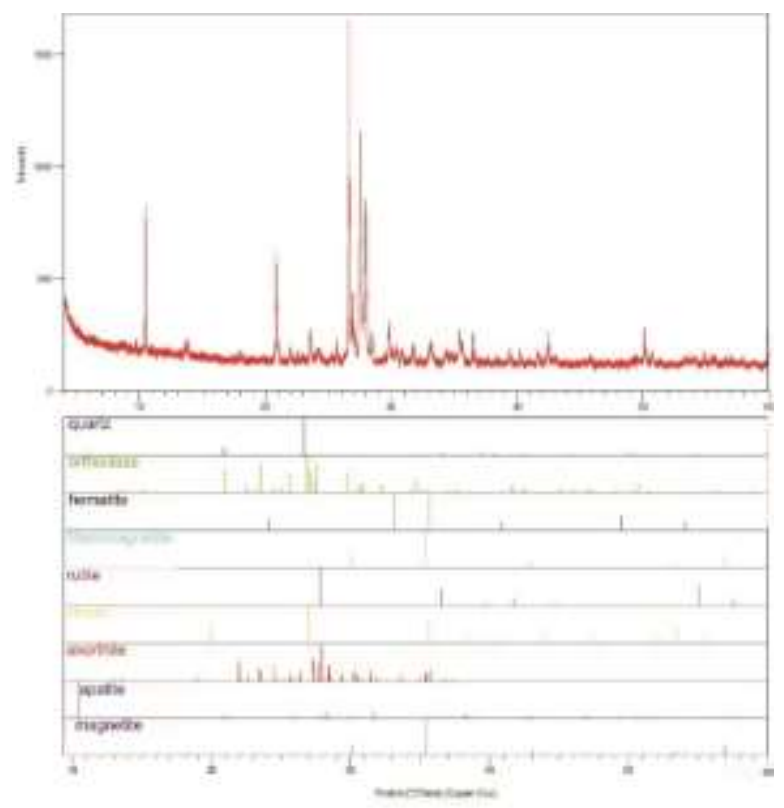

Figure 6. X-Ray diffractogram of Geyikli Heavy Mineral Sand, showing the the mineral composition. 


\section{Conclusions}

The studied rocks were described as essexites by the petrographical analysis. These essexites are located in the borders of Kestanbol pluton have significant amount of incompatible elements and can be considered as a source for REE and Th. It is concluded that these enriched elements within the Geyikli sand are related with REE bearing phosphate minerals. In Geyikli HMS, LREE contents were enriched by 4 times during placer deposition. HREE values, which are closely related with zircon minerals, were more enriched than LREE (up to 5 times). In addition to Geyikli HMS, various nearby locations such as fluvial placers or in-stu enrichments on upper parts of the granitoid body can be considered as depositions of these weathering resistant and dense REE-phosphate minerals.

The Geyikli HMS were enriched by the elements of Fe, Ti and REE-Th. Iron and titanium enrichments largely dependent on the magnetite, titanomagnetite and rutile minerals. For the large scale production, it will be wise to use the basic physical mineral processing techniques (sieving, shaking tables, multi gravity seperators, magnetic separation) to reach higher grades. These higher grade values can easily be used as a better take off point for more complex electrochemical mineral processing (flotation and solvent extraction) techniques.

\section{References}

Altunkaynak, S., Dilek, Y., Genç, C. Ș., Sunal, G., Gertisser, R., Furnes, H., and Yang, J., 2012. Spatial, temporal and geochemical evolution of Oligo-Miocene granitoid magmatism in western Anatolia, Turkey. Gondwana Research, 21(4), 961-986.

Andaç, M., Biga Yarimadasinda Ezine Siyenit Masifi ile Civarindaki Kayaçlarin Petrografisi Ve Bu Kayaçlardan Meydana Gelen Radyoaktif Sahil Plaser Maden Yataginin Etüdü, 1973 Doçentlik tezi (Istanbul, Turkey 97s: Istanbul Technical University).

Karacık, Z., and Yılmaz, Y., 1998. Geology of the ignimbrites and the associated volcano-plutonic complex of the Ezine area, northwestern Anatolia. Journal of Volcanology and Geothermal Research, 85(1-4), 251-264.

Kogarko, L., 2018. Chemical composition and petrogenetic implications of apatite in the Khibiny apatite-nepheline deposits (Kola Peninsula). Minerals, 8(11), 532.

Mugan, P. A., and İpekoğlu, B., 1995. Akçakoca-Kefken (KB Türkiye) arasında yer alan sahil kumlarının ağır mineral içerikleri. Bilimsel Madencilik Dergisi, 34(2), 27-38.

Mücke, A., and Andaç, M., 1975. Die Paragenese der Schwermineralseifen Südlich von Troja (Westtürkei). Maden Tetkik ve Arama Dergisi, 85(85).

Örgün, Y., Altınsoy, N., Şahin, S. Y., Güngör, Y., Gültekin, A. H., Karahan, G., and Karacık, Z., 2007. Natural and anthropogenic radionuclides in rocks and beach sands from Ezine region (Çanakkale), Western Anatolia, Turkey. Applied Radiation and Isotopes, 65(6), 739-747.

Pearce, J. A., Harris, N. B., and Tindle, A. G., 1984. Trace element discrimination diagrams for the tectonic interpretation of granitic rocks. Journal of petrology, 25(4), 956-983.

Sun, S. S., and McDonough, W. F., 1989. Chemical and isotopic systematics of oceanic basalts: implications for mantle composition and processes. Geological Society, London, Special Publications, 42(1), 313-345.

Whalen, J. B., Currie, K. L., and Chappell, B. W., 1987. A-type granites: geochemical characteristics, discrimination and petrogenesis. Contributions to mineralogy and petrology, 95(4), 407-419. 